\title{
すべり線の観察による高純度鉄の疲労破壞に関する研究*
}

\author{
菅 野 幹 男** 小島 公 平***
}

Observations of Slip Bands in the Study of Fatigue Fracture of High-Purity Iron

by

\author{
Mikio SugANO \\ (Faculty of Engineering, Yamagata University, Yonezawa) \\ and Kōhei KoJima \\ (Faculty of Engineering, Tottori University, Tottori)
}

There are two basic problems about fatigue, one is how cracks are formed, and the other is how they grow. The answers to these questions have been sought by investigators for a long time, but even now the problems remain substantially unsolved. Since the dawn of the use of electron microscopy for observing microstructural changes in metals, recent works have begun to shed light on the nature of basic physical processes involved in fatigue, and, on the other hand, a study to unravel the relationship between microscopic and macroscopic behaviors of materials has been urgently required. It is considered that if plastic replicas and optical microscope were prepared in one and the same horizon it would be possible to obtain the correlation of microscopic characteristics with macroscopic aspects of fatigue deformation.

In the present paper the report is given of the examination made, to clarify the basic mechanisms of fatigue fracture in b.c.c. metals, of the thin plate specimens of high-purity iron (99.996 \%) subjected to alternating bending stress. Particularly the microstructural changes that occurred around the fatigue cracks were examined by optical metallography and electron microscopy, using an improved replica technique.

The results obtained in this study are summarized as follows:

(1) The crossing points of the two slip bands are the preferred sites for fatigue crack nucleation. In these regions the aggregation of vacancies generated by the to-and-fro slip movement could form pores in the slip bands, and these in turn could grow into microcracks.

(2) There was a rather pronounced grain size effect on the nucleation and propagation of fatigue cracks. In coarse grained specimens fatigue cracks were formed preferentially in the vicinity of the grain boundaries, then spread partly along the slip bands and partly along the grain boundaries. Both the nucleation and propagation of cracks in the fine grained specimens, however, were found only in the grain boundaries.

(3) Observations with an electron microscopy disclosed that large numbers of microcracks were formed in the region where the first crack was nucreated. It is confirmed that the possible coalescence of random microcracks leads to fatal cracks.

(4) The microcracks are formed at the tip of the growing crack by the shear strain field which precedes the crack propagation. When microcracks are numerous enough, they in turn coalesce into the cracks.

(5) Observations on the surfaces have shown that substructure develops around the fatigue crack if the grain is favorably oriented, and crack propagation occurs preferentially along the subgrain boundaries.

(6) In high-purity iron, extrusions and intrusions have been observed in slip bands, and deformation bands were also formed. It is suggested that the deformations in polycrystalline materials are much complicated because of the constraints of surrounding grains.

(Received Jan. 10, 1970)

\footnotetext{
* 原稿受理 昭和45年1月10日

** 正 会 員 山形大学工学部 米冯市城南

*** 正会員 鳥取大学工学部 鳥取市湖山町
} 


\section{1 緒}

言

疲労破壞は材料が繰返し応力の作用を受け，局所的 な領域に集中して発生したすべりによって微小き裂を 形成し, その後の応力の繰返しでき裂が伝ぱする現象 と考えられる。それゆえ，材料が繰返し応力を受けて 破壞に至る過程を，(1)微小き裂を形成するまでの段階， および，(2)き裂が成長，伝ぱして破断するまでの段階 の 2 つに大別して考觉ることができる. 疲労き裂は疲 労過程のきわめて初期の段階に竹いて発生し, 疲労寿 命の大部分はき裂の伝ぱのためについやされることか ら, 従来, 多くの研究者は主として疲労き裂の伝ぱ機 構に関して取扱っている.

しかしながら，疲労破壊の現象は結晶粒のすべり帯 中に形成された微小き裂に端を発することを考えれば， き裂の発生機構を追究することもまた疲労破壊機構を 解明する5学に扣いて伝ぱ機構の研究と同様に重要で あると思われる。また，き裂を含む領域からのレプリ カ膜および実物薄膜の作製が困難であるため, き裂の 伝ぱ機構に関する研究には和もに光学顕微鏡あるいは X線が用いられてきた。X線的に得られた結果は疲労 き裂近傍はマトリックスと異なった微細化構造からな っており，疲労き裂の伝ぱと微細化構造との間には密 接な関係があることを明らかにした。一方, 電子顕微 鏡(以下，電顕と記す)による直接観察は繰返し応力を 受けた材料の表面と内部とでは明らかに転位組織すな わち変形の様相が異なっていることを示した。 これは 疲労変形機構の追究には表面の挙動を的確に追跡でき る方法を用いなければならないことを示唆するもので ある。しかし, 電顕で観察できる視野は非常に狭い領 域に限定されるために，単に電顕による観察結果だけ に基づて結晶粒あるいは試験片全体に起こった変形 の様相を知ることは不可能に近く，特定の領域からの 観察結果をもって広い領域の現象を代表させることに は常に大きな危険性を含んでいる. なた，微視的研究 と巨視的研究とがそれぞれ単独に進められている現状 において，材料を巨視的と微視的の両面から追究し， 得られる結果を統一的に解釈することが材料の本質を きわめる5えで強く要望されている。

そこで筆者らは光学顕微鏡と同一視野の中から電顕 観察用のレプリカ膜を作製し, 疲労さ裂近傍の様相を 微視的な見地から電顕観察を行ない, 光学顕微鏡によ る巨視的観察との対応のもとに疲労き裂の発生および 伝ぱ機構の検討を行なった。

\section{2 実 験 方 法}

\section{$2 \cdot 1$ 試験片および疲労試験機}

使用した材料は市販の高純度鉄（99.996 at. \%) で， その化学組成を Table I に示した，厚さ $0.25 \mathrm{~mm}$ の 薄板材より Fig. 1 に示す標準寸法を有する試験片を作
Table I. Chemical composition (ppm)

\begin{tabular}{c|c|c|c}
\hline $\mathrm{C}$ & $\mathrm{S} 1$ & $\mathrm{Mn}$ & $\mathrm{P}$ \\
\hline 8.0 & $<0.5$ & $<01$ & 03 \\
\hline $\mathrm{S}$ & $\mathrm{N}$ & 0 & Others \\
\hline 1.2 & 7.0 & 7.2 & 157 \\
\hline
\end{tabular}

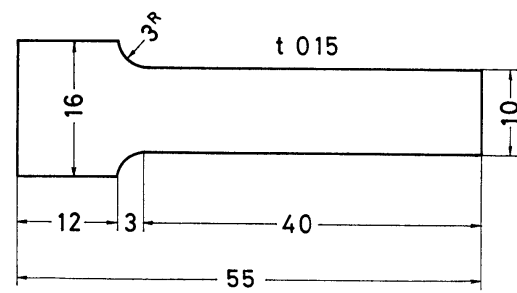

Fig. 1. Fatigue test specimen.

製し，結晶粒を粗大化させるために真空中 $950^{\circ} \mathrm{C} て ゙ 10$ 時間保持の完全焼なるし処理を行なった．表面はエメ リー紙 700 番まで機械研摩し，真空中 $750^{\circ} \mathrm{C}$ で10時間 保持のひずみ取り焼なましを行なった後，加工変質層 の除去および組織観察のため正燐酸一アルコール溶液 を用いた電解研摩により表面層約 $35 \mu$ を溶去した。 仕上げた試験片の厚さは約 $0.15 \mathrm{~mm}$ で, 平均結晶粒 径は約 $5 \mathrm{~mm}$ であった，乙たがって，試験片は厚さ 方向にそれぞれ貫通している単一層の結晶粒から構成 されているものである. 実験に使用した疲労試験機は 自製の電磁共振型繰返し曲げ疲労試験機である。本実 験では繰返し応力下で生じた組織の観察に便利なため 2 次の振動型を採用したが，そのときの共振周波数 は300〜 $450 \mathrm{c} / \mathrm{s}$ の範囲となり, 疲労限は $12.5 \mathrm{~kg} / \mathrm{mm}^{2}$ である。

\section{$2 \cdot 2$ レプリカ膜の作製および組織の観察}

深い疲労き裂を含む領域の電顕観察はレプリカ膜自 体が非常に破壞しやすく, 普通の二段カーボンレプリ カ法ではレプリカ膜の作製が困難であるためにこれま でもあまり行なわれてないようである。そこで筆者ら は膜の補強とまるまりの防止のためにシャドウイング と蒸着を交互に 2 回ずつ施し，Fig. 2 に示すような層 状のレプリカ膜を作製することを試み，疲労き裂近傍 からのレプリカ膜の作製にかなりの成果を和さめるこ とができたレプリカ膜にはセルロースアセトブチラ ート膜を使用し，シャドウイングにはCrを用いて $45^{\circ}$ 方向より施した。

光学的な視野と同一領域よりレプリカ膜を作製する についてはカーボン蒸着を施した膜を光学顕微鏡下で 観察しながら対応する結晶粒を探し出し，目的の領域 を切取った。以後は普通の方法でカーボンの蒸着膜を メッシュにすくい,さらに光学顕微鏡により目的の場 


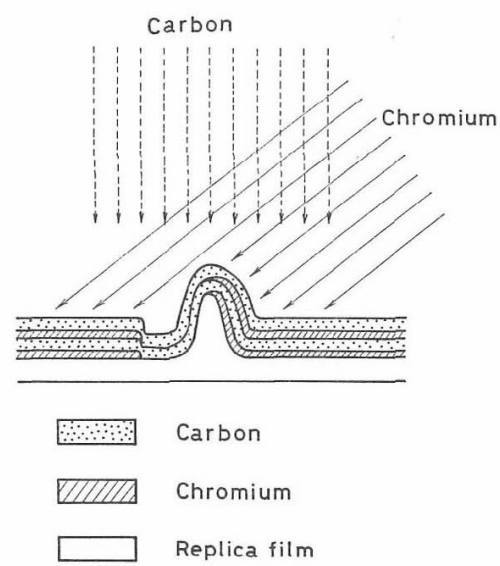

Fig. 2. Schematic representation of the improved replica technique.

所がメッシュ上に占める位置るあらかじめ確認した後, 電顕で検鏡した。組織の観察には光学顕微鏡就よび電 子顕微鏡（日立製 HU-11 型）を使用した。電子顕微 鏡の加速電圧は $100 \mathrm{kV}$ である。

\section{3 実 験 結 果}

\section{$3 \cdot 1$ すべり線の形態}

繰返し応力の作用を受けて発生するすべり線と疲労 き裂の発生拈よび伝ぱとの間に密接な関係が存在する ことは良く知られている。 Fig. 3 (a)は変形の様相が同 一結晶粒内に执いて場所飞よって相違している例であ
る、これはA，B両領域で変形に関与したすべり系が 異なったために生じた現象と思われる。(b)結晶粒内 の一部に発生した変形帯 (Deformation band) であ る。Fig. 4 (a)は繰返し応力の作用を受けて形成された intrusion であり，(b)はすべり帯内に発生したき裂を 示す.すべり帯領域には多数の小孔 (Pore) が存在し, 小孔の列はき裂へ進展する前の状態に相当するるのと 推測され，すべり带き裂の発生と小孔との間の密接な 関係を知ることがでさる。

\section{$3 \cdot 2$ 光学的観察との対応}

光学顕微鏡で観察できる視野と同一領域からレプリ カ膜を作製し，電顕により観察した結果ととの周团の 変形の様相とを対応させた。Fig..5 は党裂近傍の結晶 粒に観察されたすべり線を示す。. (a)は光学写真であり, 変形の様相は場所によってかなり異なることを示して

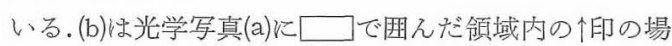
所に対応すると思稀れる intrusion の電顕写真である。 この intrusion 部分では長手方向と垂直な方向にもす ベり跡が存在し, この領域に交差すべりが特に集中し て起こったことを物語っている。これは intrusionの 形成に交差すべりが重要な役割を演じていることを意 味する.Fig. 6 は疲労させた試験片表面から作製した レプリカ膜の光学写真 $(a)$ と先電顕写真( $(b)$ 掞上び(c)で 西る。(b)は(a)中㳻在して観察される黒いはえ点状の 一領域に該当し、はん点として認められる部分はすべ り帯が互いに交差する点に発生した微小 き裂であることが知られる。さらに(c)は 繰返し応力下に特いて正負のすべりが特 定の領域で多数回繰り返される間に形成 された小孔が結晶粒表面で集結した状態 を示し, (b)に観察されたき裂の初期段階 に相当するもの之推測される。Fig. 7 は 破断にまで成長した主疲労き裂からき裂 進展方向飞対して垂直な方向へ 600 離れた同一結晶粒について疲労過程に抢 ける变形挙動を追跡したるのである。(a),

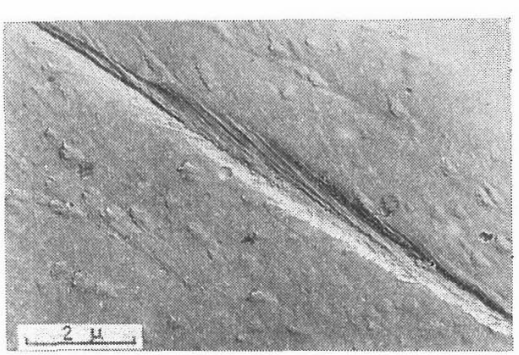

(a)

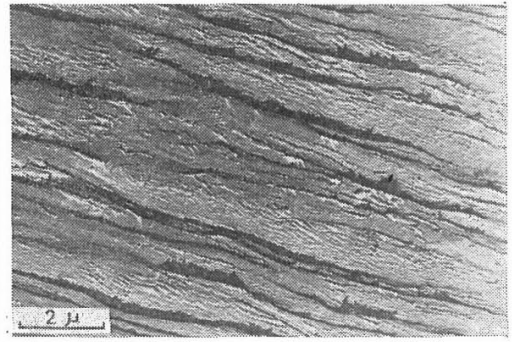

(b)

Fig. 4. Aspects of slip bands :

(a) Intrusions in slip bands

(b) Crack growth associated with the coalescence of pores $\sigma=18.6 \mathrm{~kg} / \mathrm{mm}^{2}, N=7.8 \times 10^{5}$ 


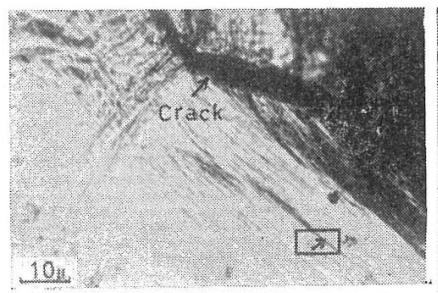

(a)

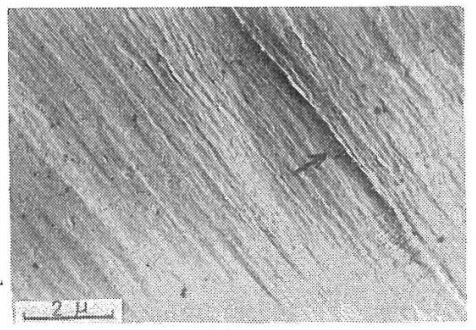

(b)

Fig. 5. Appearance of slip bands formed in the vicinity of fatigue cracks:

(a) Optical micrograph showing macroscopic aspects of the grains situated fatigue crack

(b) Electron micrograph showing intrusion in slip bands $\sigma=17.5 \mathrm{~kg} / \mathrm{mm}^{2}, \quad N=1.8 \times 10^{6}$

(a)

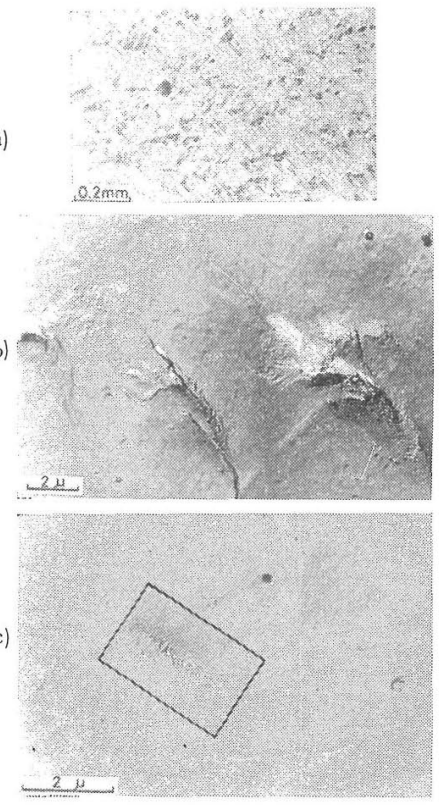

Fig. 6. Formation of microcracks :

(a) Optical micrograph showing microcracks dispersed in fatigued grain

(b) Electron micrograph showing microcracks formed at the crossing points of two slip bands (c) Electron micrograph showing pores along slip bands

$\sigma=18.6 \mathrm{~kg} / \mathrm{mm}^{2}, \quad N=7.8 \times 10^{5}$

(b)は光学写真で，(a)は試験片の疲労寿命の〜 50\%，(b)

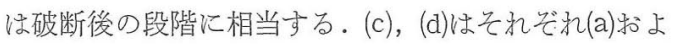
び(b)に対応する䉓顕写真で岗る. 光学的観察結果には 頙著な差異を認るがたいが, 電頙観察の結果では寿命 の〜50\%の段階(c)でその形跡がまだはっきりと認めら れなかった小孔が，破断後に相当する(d)ではすべり帯 領域に多数観察される。(c)，(d)飞执いてすべり帯間隔 に卧とえど差はなく，すべり帯領域の小孔の有無およ び(d)の左端に観察される交差すべりの跡の久が両者の 違いである。

\section{$3 \cdot 3$ 疲労き裂の発生亡伝ぱ}

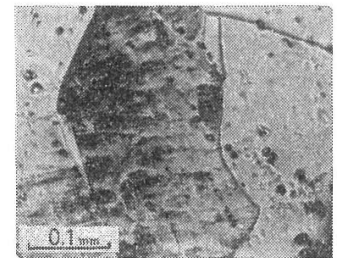

(a)

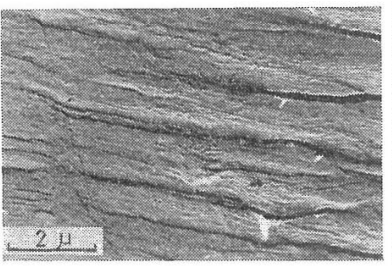

(c)

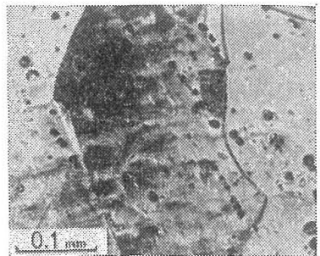

(b)

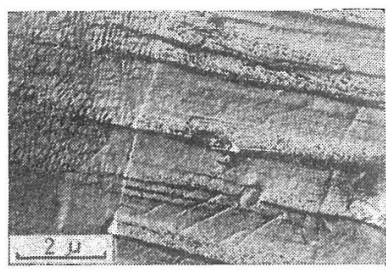

(d)
Fig. 7. structural changes of the same grain at successive stages during fatigue:

(a) and (b) Optical micrographs showing aspects of the same grain after about 50 per cent of fatigue life and after fracture

(c) and (d) Electron micrographs corresponding to (a) and (b) respectively, showing characteristic rows of pores formed in slip bands

$\sigma-22.9 \mathrm{~kg} / \mathrm{mm}^{2}$, (a) and (c) $N-2.1 \times 10^{5}, \quad$ (b) and (d) $N=4.0 \times 10^{5}$

$3 \cdot 3 \cdot 1$ 巨視的観察 Fig. 8 以疲労過程の各段階 飞和ける同一領域の組織の变化を光学顕徽鏡により追 跡したるのである。加光た応力 $(\sigma)$ は $18.2 \mathrm{~kg} / \mathrm{mm}^{2}$ で破断までの繰返し数 $(N)$ は $4.7 \times 10^{5}$ である。各 図に括いて个印は対応する場所を示す。( ( は初にき 裂が発生した場所である(寿命の〜28\%)。2 個所に独 立してき裂の発生が認められ，いずれも絬晶粒界の近 傍である.(b)の段階（４5\%) では(a)に観察されたき 裂のほかに左方へ新にき裂が発生している。(c) はさら に疲労過程が進行した後（５8\%）飞相当し，図の右 方にはやはり結晶粒界の近傍に新たなき裂の発生が認 められる。この段階に和いてもき裂は先れ㢳れ独立し たままの状態を保ら続けるが，破断後の(d)に至ってそ 水音で個々に存在し続けたき裂はそれ炎机結晶粒界を 


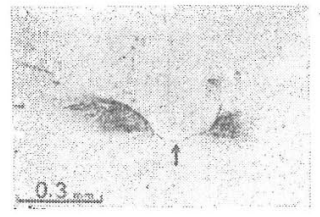

(a)

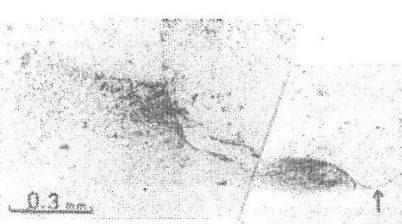

(b)

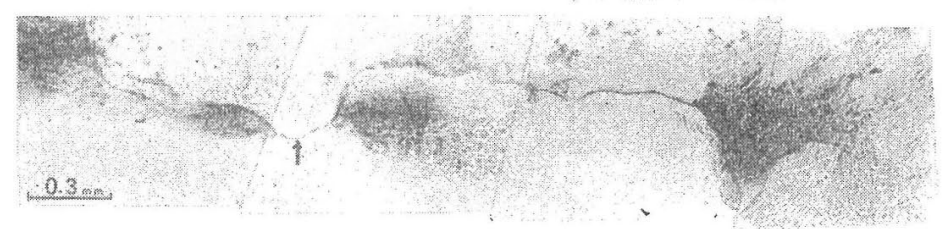

(c)

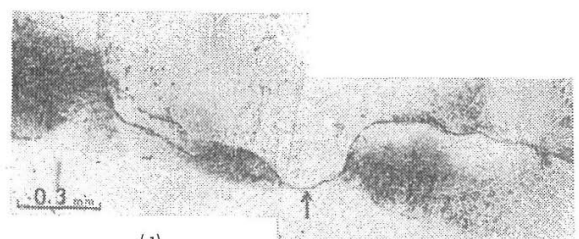

(d)

Fig. 8. Formation and propagation of cracks in coarse grained specimen at various stages during fatigue :

(a) $N=1.3 \times 10^{5}, \quad$ (b) $N=2.1 \times 10^{5}, \quad$ (c) $N=2.7 \times 10^{5}, \quad$ (d) $N=4.7 \times 10^{5}, \sigma=18.2 \mathrm{~kg} / \mathrm{mm}^{2}$

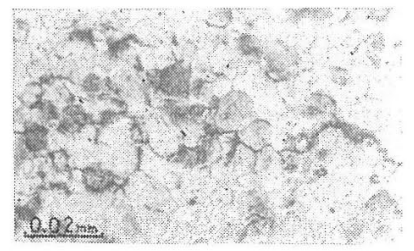

Fig. 9. Formation and propagation of cracks in fine grained specimen at fractured stage after cyclic loading.

$\sigma=16.0 \mathrm{~kg} / \mathrm{mm}^{2}, \quad N=2.1 \times 10^{6}$

伝ぱ径路として結合し，破断き裂に成長している。京 た，(b)の段階以後は最初にき裂が発生した領域にほと んど変化が認められない.Fig. 9 は〜 $5 \mu$ 程度の微細 な結晶粒からなる試験片に $16.0 \mathrm{~kg} / \mathrm{mm}^{2}$ の繰返し応 力を与え疲労させたとさの破断時におけるき裂近傍の 様相である $\left(N=2.1 \times 10^{6}\right)$.この場合き裂はすべて結 晶粒界に発生し, 伝ぱも粒界上に起こる。

$3 \cdot 3 \cdot 2$ 微視的観察 Fig. 10 (a)はFig. 8(a)（ $\sigma=$ $\left.18.2 \mathrm{~kg} / \mathrm{mm}^{2}, N=1.3 \times 10^{5}\right)$ と同じもので，痩労き

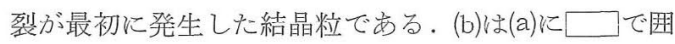
んだ領域内の个印の場所に対応すると思われる電顕写 真で, 痩労き裂が発生した領域には多数の微小き裂が 無秩序に存在し，これら微小さ裂が順次結合すること によってき裂は成長することを示す．Fig. 11は結晶粒 内を伝ぱする疲労き裂先端領域の電顕写真である。(a) はき裂先端より数 $10 \mu$ 離れた領域に観察されたもの で，数 程度の大きさからなる subgrain が認められ
る・なた， subgrain 境界上には多数の小孔といくつ かの微小き裂があって，ここでも僆小き裂と小孔との 強い関連性を察知できる。(b)はき裂の先端部分に相当 守る。疲労き裂は subgrain 境界上を伝ぱして扮り， (b)は(a)が進行した状態を走している。これらの結果よ り結晶粒内を伝ぱする疲労き裂の先端には subgrain が存在し, き裂は subgrain 境界上を小孔の集結に起 因する微小さ裂の連係によって進展していることが分 る.Fig. 12 はき裂の両側に発達した微細化構造であ

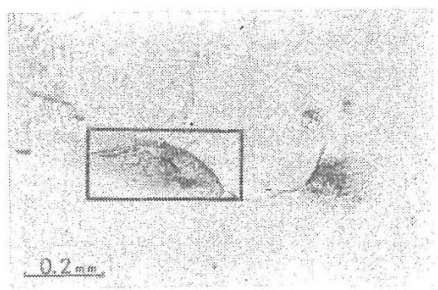

(a)

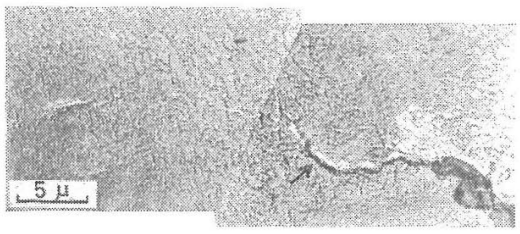

(b)

Fig. 10. Microstructure of the same grain as shown in Fig. 8 (a):

(a) Optical micrograph showing macroscopic aspects of the cracked parts of specimen

(b) Electron micrograph showing microcracks formed in the vicinity of cracks 


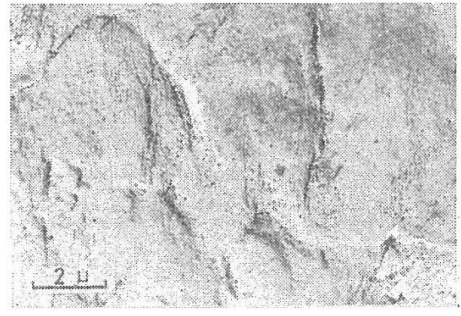

(a)

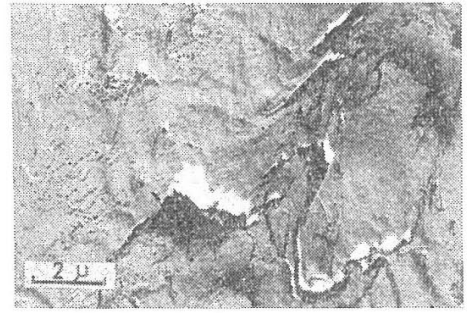

(b)

Fig. 11. Substructure formed at the tip of crack:

(a) Appearance of substructure at the head of crack

(b) Fatigue crack propagation along subgrain boundaries $\sigma=17.5 \mathrm{~kg} / \mathrm{mm}^{2}, \quad N=1.8 \times 10^{\circ}$

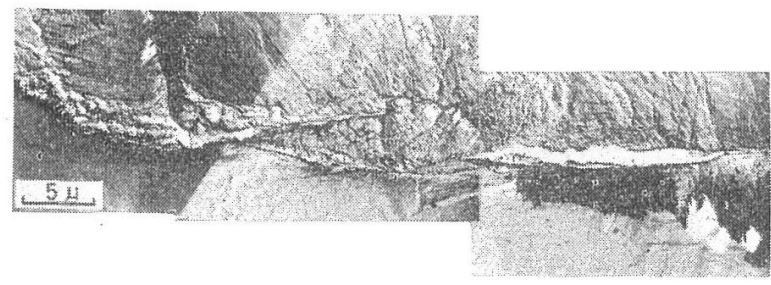

Fig. 12. Substructure developed around fatigue cracks. $\sigma=22.9 \mathrm{~kg} / \mathrm{mm}^{2}, \quad N=4.0 \times 10^{5}$

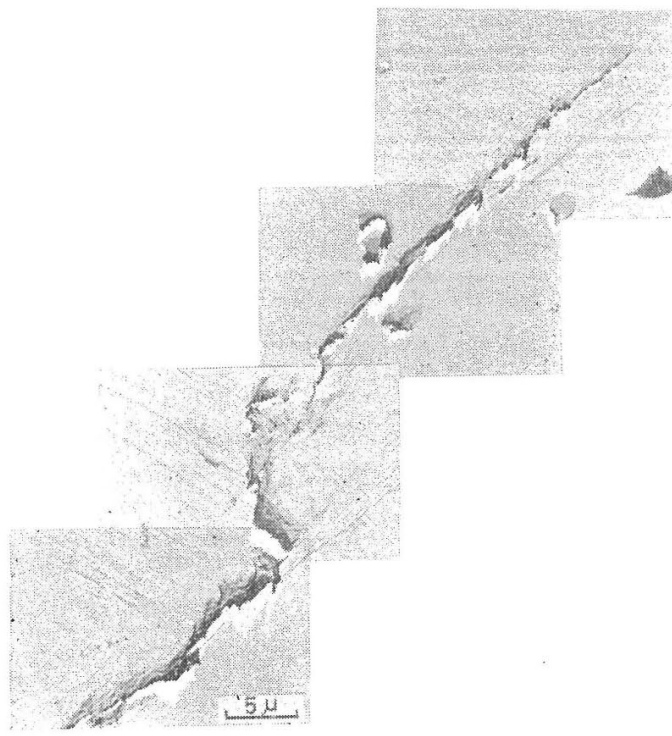

Fig. 13. Appearance of fatigue cracks propagating along grain boundaries.

$\sigma=17.5 \mathrm{~kg} / \mathrm{mm}^{2}, \quad N=1.8 \times 10^{6}$

る。結晶粒界上に発生した疲労き裂の進展の様相を示 したものが Fig. 13 である。き裂は先端に微小き裂を 形成しながら伝ばする。

\section{4 考}

察

従来, 疲労き裂の発生はf.c.c. 金属について多く 観察されているよらな intrusion や extrusion 等に 起因するすべり帯き裂, 市るいは, 結晶粒界や介在物 と転位との相互作用により形成されるくさび型き裂の ように軽位論に基ついたモデルで説明されてきた。し
かしながら，従来のどの機構もFig. 6 に観察され たような幑小き裂の発生を説明するには必らずし も適当でない：そこで，このよ5なき裂の発生に ついて筆者らは次のような機構を考えた。すなわ ๖，Fig. 6 に和いて微小き裂はいずれも多重すべ りの交差する点に発生している。繰返し応力高 けて最初に活動したすべり系Iは遅れて活動を開 始したすべり系II対し障害壁となるであるう (Fig. 14). 障害壁によって運動を阻止された転位が back stress と均衡を保っている場合には，運動中の 転位の運動方向を逆転させるに必要な応力に比較して 小さな逆向きの応力で転位は移動できるものと考帛ら 孔る。したがって，応力繰返しの過程で転位は往復運 動が可能でめり，転位間の切合いによる点欠陷の形成 が起こることも推測できる. 結晶粒の表面は点欠陥の 有力な消滅場所の 1 つで充るから, 疲学過程の進行と ともに筆者らが表面に観察したような小孔を形作るる のと思わ机る。Fig. 6 (c)は小孔形成の段階に相当し， また(b)は小孔から発達した微小き裂である。このよ5

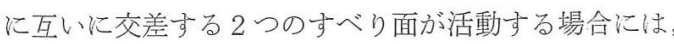
その交点は微小き裂の有力な発生場所となり得るもの である.Fig. 7 (d)をシャドウイングの方问と写真の黒 化度とから判断して図式的に表わしたのが Fig. 15 で ある.すべり帯領域の起伏はすでに(c)の段階（寿命の 〜 50\%) で認められるが，まだ小孔は確認できない。

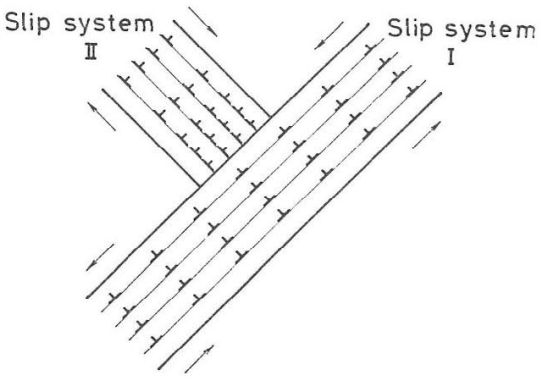

Fig. 14. Mechanism of microcrack formation at the crossing point of two slip bands shown in Fig. 6 . 


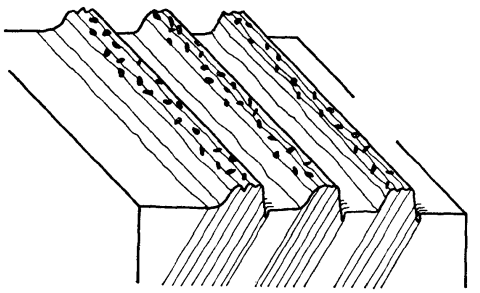

Fig. 15. Schematic transverse sections through persistent slip bands shown in Fig. 7 (d).

これは(d)との比較により小孔は疲労過程が相当に進行 した段階で現われることを意味する。少孔形成の時期 そついてはW. A. Wood らの結果と必らずしも一致し ないが，これは材料が異なること以外に観察方法の相 違に起因しているように思われる。W.A. Wood らが 行なった斜め切断法による場合は完全に小孔を形作る 前においても腐食液の作用で小孔と同じょうな形に観 察される可能性は充分考兄られる。筆者らの結果から， 小孔と微小き裂形成との間に密接な関係が存在するこ とは明らかである (Fig. 4 (b)，6)。

巨視的な観察結果は疲学き裂の発生㧍よび伝ぱの形 態が結晶粒度に依存することを示した（Fig. 8，9）。 粗大結晶粒 (平均粒径 $5 \mathrm{~mm}$ ) では, き裂は結晶粒界 付近の局所的な領域飞互いに独立して発生し, 疲労過 程の進行に伴いき裂はある長さにまで成長するが，そ の数も増加する. その後は個々に独立を保っていたき 裂が結晶粓界を伝ぱして互い汇連係し，終局的な破断 へと進展する。また，電顕観察の結果（Fig. 11，12） から，き裂が結晶粒内を伝ぱするときの様相としてき 裂の先端掞よび両側には subgrain を形成し, き裂は subgrain 境界上を優先的に伝ぱすることが知られる. これはすでに得られた細束X線および透過電顕にょる 観察結果と一致するが, 疲労させた試駼片の表面観察 によって確認している報告はないようである.表面観 察においては他の方法と異なり，このような現象はき 裂が粒内を伝ぱするとき常潅察されるとは限らない が，それはこの現象が結晶粒の方位に依存する性質の ものであるためと考光られる。

一方, 細結晶粒 (平均粒径数 $\mu$ 程度) 試験片では, 疲労き裂の発生も伝ぱも結晶粒界上に起こる (Fig. 9). 繰返し応力下で形成される subgrain の大きさは鉄の 場合数 $\mu$ 程度と言われているが, 最初から数 $\mu$ 程度の 結晶粒からなる試験片において個々の結晶粒が示す挙 動は粗大結晶粒試験片の場合飞形成された subgrain の挙動と類似しているように思われる。細結晶粒試験 片では粒界による拘束が大きいために，結晶粒は微細 化を起こす汪ど大きな変形は困難となり, き裂の発生 子伝ぱも它しろ粒界に起こりやすくなるものと思われ る。このように, き裂の発生伝ぱの形態は結晶粒の大
きさと密接な関係があり， subgrain 形成の難易度に 大い依存するものと考光られる。

多結晶体試験片で個々の結晶粒に作用する応力は周 囲からの拘束を受汓るため, 引張りや圧縮の単純な繰 返しではなく，多成分を有する応力が同時に作用する であろう。その結果, 結晶粒（または粒内の局所的領 域）は外力に対して結晶構造上最も有利なように変形 し，変形帯等も出現するものと考光られる (Fig. 3).

\section{5 結 言}

横振り繰返し曲げ疲労試験を行なった高純度鉄の薄 板状試験片について疲労き裂近傍の組織を光学顕微鏡 抒よびレプリカ法電子顕微鏡により観察した結果, 次 の事項が明らかとなった。

(1) 多重すべりが交差する点は疲労き裂の有力な発 生場所であり，このときのき裂の生成はすべり帯中に 形成された小孔（Pore）飞起因するものである.

(2) 疲労き裂の発生就よび伝ぱの形態は結晶粒度に 依存する。粗大結晶粒では, き裂の発生は結晶粒内で も粒界飞近い領域に起こり, 粒内と粒界を伝ぱする。 細結晶粒では, き裂の発生も伝ぱも常に粒界が優先す る.

（3）疲学過程の初期に执いてすべり帯に起伏を生じ， 次いで小孔が形成される。これらの小孔は疲労過程の 進行とともに結合, 成長してすべり帯き裂へと発達す る。

（4）結晶粒内で最初にき裂が発生した領域には多数 の微小き裂が存在し，き裂はこれら微小き裂の連係化 よって成長するととるに, き裂の伝ぱは先端微小き 裂を形成しながら順次とれらと結合して進展する。

（5）疲労き裂が結晶粒内を伝ぱするとき，き裂の近 傍には subgrain が形成される。裂は subgrain 境 界上を優先して伝ぱする。

（6）高純度鉄飞执いてもすべり帯領域に intrusion や extrusionが観察された。また，ある結晶粒内には 変形帯も認められた。

終わりに, 本研究の実施にあたり電子顕微鏡につい てご㖃篤なるご指導を賜った是枝淳夫氏（大阪大学産 業科学研究所) 飞深甚の謝意を表すとともに, 本研究 の一部は松永記念科学振興財団昭和 41 年度研究助成金 により行なわれたものであり，ここに厚く感謝の意を 表す次第である。

(昭和42年 9 月 8 日 第11回材料研究通合講窝会にて講演)

\section{参 考文 献}

1) Wood, W.A., J. Inst. Met., 91, 225 (1962-63).

2) Wood, W. A., S. McK. Cousland, and K. R. Sargant, ıbrd., 91, 304 (1962-63).

3) Holden, J., Phil. Mag., 6, 547 (1961). 
4) 平 修二, 林 建吉, 日本機械学会論文集, 32,389 (1966).

5) 平 修二, 林 建吉, $\imath b \imath d ., 33,1$ (1967).

6）辛島誠一, 及川 洪, 小倉次夫, 日本金属学会誌, 31 , 669 (1967).

7) 菅野幹男, 小島公平, 日本機械学会米沢地方講演会講演 論文集, 78 (1969).

8) Wei, R.P., and A. J. Baker, Phil. Mag., 11, 1087 (1965).

9) Klesnil, M., and P. Lukáš, J. Iron Steel Inst., 203, 1043 (1965).

10) Karashima, S., and M. Takamura, Tech. Repts. Tōhoku Univ., 26, 85 (1962).

11) Thompson, N., N. Wadsworth, and N. Louat, Phil. Mag., 1, 113 (1956).

12) Forsyth, P. J.E., J. Inst. Met., 80, 181 (1951-52).
13) Forsyth, P. J.E., Proc. Roy. Soc., A 242, 198 (1957).

14) Mott, N. F., Phil. Mag, 43, 1151 (1952).

15）たと党ば Cottrell, A. H., and D. Hull, Proc. Roy. Soc., A 242, 211 (1957).

16）横堀武夫, “材料強度学”, p. 115 (1964) 岩波

17) Cottrell, A. H., "Dislocations and Mechanical Properties of Crystals", p. 509 (1957) Wiley

18) Wood, W.A., W.H. Reimann, and K. R. Sargant, Trans. AIME, 230, 511 (1964).

19) Grosskreutz, J.C., and P. Waldow, Acta Met., 11, 717 (1963).

20）辛島誠一, 及川 洪, 小倉次夫, 日本金属学会誌, 31, 674 (1967).

21) Sugano, M., and K. Kojima, Mem. Inst. Sci. Res. Osaka Univ., 23, 55 (1966). 